\title{
From lamps to lasers
}

Willem D. Hackmann

The GEC Research Laboratories 1919 1984. By Robert Clayton and Joan Algar. Peter Peregrinus/Institution of Electrical Engineers: 1989. Pp.438. £40. Available in the US from IEEE Service Center, 445 Hoes Lane, Piscataway, New Jersey 08855, USA, price $\$ 80$.

THE oldest British government-sponsored laboratory was the Royal Observatory at Greenwich, established by Charles II to improve navigation. As the ensuing decades turned into centuries, government agencies came increasingly to rely on scientific expertise, the eventual result of which was the creation of the National Physical Laboratory (NPL) in 1897. This establishment formed the pattern for subsequent state and commercial laboratories in Britain (now, in the case of state laboratories, being reversed), but American and German firms were quicker off the mark in creating such facilities. Thomas Edison's establishment, first at Menlo Park (1876) and then at West Orange, New Jersey (1887), was the largest privately funded laboratory in the world at that time, and epitomized the transition from the nineteenth-century lone inventor-entrepreneur to organized twentieth-century industrial research, creating new products and markets.

There is scant information on the early development of commercial research laboratories in Britain, in part because many firms have destroyed their archives. Robert Clayton and Joan Algar have produced a densely written book about one of Britain's best-known commercial research centres, the General Electric Company Research Laboratories at Wembley (later called the GEC Hirst Research Centre after the company's chairman and managing director who founded the laboratory). It must be said, though, that this is not so much a history as a chronology of events, concentrating on scientific and organizational developments and not on people. The only personality of which we get a glimpse is the first director, Sir Clifford Paterson, a somewhat austere figure with distinctive views on research.

During the First World War, Paterson was working at the NPL in charge of the Electrotechnics Department and Photometry, with contacts at the Osram Lamp Works (then a separate company founded jointly by the DGA of Berlin and GEC of England). Thus it was natural that he should be approached by GEC and Osram to give advice on the setting-up of a research facility, so that the English company would be independent of German science. Indeed the First World War had a great effect on English industrial and government research, which had to be re-organized to make up for the loss of German technical products.

In the event, Paterson undertook the task of building up the GEC Research Laboratories himself. The facility was opened in 1923 by Sir J. J. Thomson, the Cavendish professor of experimental physics at Cambridge and Master of Trinity College, and the Member of Parliament, Lord Robert Cecil. Even by the standards of the period, Paterson's ideas were unorthodox: the administration was kept to a minimum, the main structure of the research organization remained in the hands of scientists, and the commercial management of GEC did not interfere with the scientific work. Paterson held strong views, not least on punctuality. When, during the war, one employee blamed bad time-keeping on a broken alarm clock, Paterson provided a new one and duly debited the cost at the end of the following month. The centre's organization only started to change drastically after Paterson's death in 1948.

The authors have made little attempt to place the developments at Wembley in a wider context, except when they are related to specific research elsewhere. The first two chapters are the most historical. After dealing with the "origins, philosophy and organisation" of the laboratory, a synoptic outline is given of the main research work by decade, from the 1920 s until 1984 . This account is amplified in the next 14 chapters on work done by the various sections of the laboratory, written by specialists from these sections. Thus we have chapters on lamps and valves (the initial stimulus for the laboratory's existence), cathode-ray tubes, communications and electronics, semiconductors, physics (mostly solid-state), lasers and optoelectronics, glass and refractory materials, metallurgy, and chemistry.

Next follows an entire chapter devoted to research during the Second World War, which, although carried out for the most worthy patriotic sentiments, stood GEC in good stead in the early post-war period. Highlights are GEC's contribution to magnetron research (starting with the glass-envelope magnetrons of the early 1930s), the development of the RandallBoot cavity magnetron (which was handed over to the United States by the Tizard Mission in 1940), airborne radar for fighter planes, radar for gun-laying and 'blind-bombing', and acoustic torpedoes. The final, brief chapters deal with statistics and quality control (GEC was a pioneer in the application of statistical methods), patents and publications.

The authors point out that this history is almost entirely based on first-hand accounts, primarily technical reports. The book itself is cast in the style of a scientific monograph, giving fascinating insights into the workings of an industrial laboratory and showing in microcosm what has happened in general in British commercial research during the twentieth century. In particular, one is struck by the fact that the backbone of commercial research is based not on epoch-making discoveries or on flashes of genius, but on careful, meticulous work leading to steady progress.

Willem D. Hackmann is Assistant Curator in the Museum of the History of Science, University of Oxford, Old Ashmolean Building, Broad Street, Oxford OX1 3AZ, UK.

\section{IMAGE UNAVAILABLE FOR COPYRIGHT REASONS}

